\title{
Coastal Ocean and Nearshore Observation: A French Case Study
}

\author{
Lucie Cocquempot ${ }^{1,2 *}$, Christophe Delacourt ${ }^{1}$, Jérôme Paillet ${ }^{2}$, Philippe Riou ${ }^{2}$, \\ Jérôme Aucan ${ }^{3}$, Bruno Castelle ${ }^{4}$, Guillaume Charria ${ }^{5}$, Joachim Claudet ${ }^{6}$, Pascal Conan, \\ Laurent Coppola ${ }^{8}$, Régis Hocdé ${ }^{9}$, Serge Planes ${ }^{10}$, Patrick Raimbault ${ }^{11}$, Nicolas Savoye ${ }^{5}$, \\ Laurent Testut ${ }^{12}$ and Renaud Vuillemin ${ }^{7}$
}

\begin{abstract}
'Laboratoire Géosciences Océan (LGO), UMR6538 (Univ. Brest/CNRS/UBS), European Institute for Marine Studies (IUEM), Plouzané, France, ${ }^{2}$ Département Océanographie et Dynamique des Ecosystèmes (ODE), Ifremer, Plouzané, France,

${ }^{3}$ Laboratoire d'Etudes en Géophysique et Océanographie Spatiales (LEGOS), UMR5566 (CNRS/CNES/IRD/UPS), University of Toulouse, Toulouse, France, ${ }^{4}$ Environnements et Paléoenvironnements Océaniques et Continentaux (EPOC), UMR5805 (CNRS/Univ Bordeaux/EPHE), OASU, University of Bordeaux, Pessac, France, ${ }^{5}$ Laboratoire d'Océanographie Physique et Spatiale (LOPS), UMR6523 (Ifremer/Univ. Brest/CNRS/UBO/IRD), European Institute for Marine Studies (IUEM), Plouzané, France, ${ }^{6}$ Centre de Recherches Insulaires et Observatoire de l'Environnement (CRIOBE), USR3278 (CNRS/EPHE/UPVD), PSL Université Paris, Paris, France, ${ }^{7}$ Laboratoire d'Océanographie Microbienne (LOMIC), UMR7621 (Sorbonne Université/CNRS), Observatoire Océanologique de Banyuls, Sorbonne Université, Banyuls-sur-Mer, France, ${ }^{8}$ Laboratoire d'Océanographie de Villefranche (LOV), UMR7093 (Sorbonne Université/CNRS), Institut de la Mer de Villefranche (IMEV), Villefranche-sur-Mer, France, ${ }^{9}$ Marine Biodiversity, Exploitation and Conservation (MARBEC), University of Montpellier, UMR9190 (CNRS/IFREMER/IRD), Montpellier, France, ${ }^{10}$ Centre de Recherches Insulaires et Observatoire de I'Environnement (CRIOBE), USR 3278 (CNRS/EPHE/UPVD), PSL Research University, Perpignan, France, "11 Mediterranean Institute of Oceanology (MIO), UMR7294, UM 110 (CNRS/INSU/IRD), University of Aix-Marseille, Marseille, France, ${ }^{12}$ LIttoral ENvironnement et Sociétés (LIENSs), UMR7266 (CNRS/Univ. La Rochelle), Institut du Littoral et de l'Environnement, La Rochelle, France
\end{abstract}

OPEN ACCESS

Edited by:

Sabrina Speich,

École Normale Supérieure, France

Reviewed by:

Anna Rubio,

AZTI, Spain

Maria Snoussi,

Mohammed V University, Morocco

*Correspondence:

Lucie Cocquempot lucie.cocquempot@ifremer.fr

Specialty section:

This article was submitted to Ocean Observation,

a section of the journal Frontiers in Marine Science

Received: 04 December 2018 Accepted: 28 May 2019 Published: 25 June 2019

Citation:

Cocquempot L, Delacourt C, Paillet J, Riou P, Aucan J, Castelle B, Charria G, Claudet J, Conan $P$, Coppola L, Hocdé R, Planes S, Raimbault P, Savoye N, Testut $L$ and Vuillemin $R$ (2019) Coastal Ocean and Nearshore Observation: A French

Case Study. Front. Mar. Sci. 6:324. doi: 10.3389/fmars.2019.00324
To understand and predict the physical, chemical, and biological processes at play in coastal and nearshore marine areas requires an integrated, interdisciplinary approach. The case study of the French structuration of coastal ocean and nearshore observing systems provides an original overview on a federative research infrastructure named ILICO. It is a notable example of national structuration and pan-institution efforts to investigate the forefront of knowledge on the processes at work within the critical coastal zone. ILICO comprises, in a pluridisciplinary approach, eight distributed networksystems of observation and data analysis that are accredited and financially supported by French research institutions and the French Ministry for Higher Education, Research, and Innovation. ILICO observation points are implemented along metropolitan and overseas French coasts, where coastline dynamics, sea level evolution, physical and biogeochemical water properties, coastal water dynamics, phytoplankton composition, and health of coral reefs are monitored in order to address a wide range of scientific questions. To give an overview of the diversity and potential of the observations carried out, this paper offers a detailed presentation of three constituting networks: Service Observation en Milieu LITtoral (SOMLIT), with homogeneous sampling strategies, DYNALIT, with heterogeneous sampling strategies adapted to different environments, and Mediterranean Ocean Observing System for the Environment (MOOSE), an integrated, pluri-disciplinary coastal/offshore regional observatory in the north-western Mediterranean Sea. ILICO was conceived using a European framework. It addresses the great challenges of the next decade in terms of sustainability, cost-efficiency, interoperability, and innovation. This paper emphasizes the added-value of federating these systems, and highlights some recommendations for the future.

Keywords: observation infrastructure, national structuration, interdisciplinary, coastal ocean, coastline 


\section{INTRODUCTION - CHALLENGES AND MOTIVATIONS OF AN INTEGRATED COASTAL OCEAN AND NEARSHORE OBSERVATORY}

The coastal ocean and nearshore zones are complex areas featuring diverse bio-physico-geomorphological environments, rich in potential scientific knowledge and exposed to numerous strategical economic and ecological stakes. Multiple definitions of coastal systems can be found among the Ocean observation bibliography (Davis and Ethington, 1976; Lorenzoni and Benway, 2013; Baschek et al., 2017; Petihakis et al., 2018). This paper considers the nearshore zone as the area where land and water join to create an environment with a distinct structure, diversity, and flow of energy.

Being a transitional space directly subject to anthropic activities, the nearshore area is subject to multiple forcings at various spatial and temporal scales. Its evolution raises various scientific issues, which are meant to be addressed by the integrated observation system described in this paper:

- Understanding the physical, chemical, and biological processes at work in the systems general dynamics.

- Characterizing and understanding the long-term changes of these systems and the specific role of climate change in the process.

- Understanding and quantifying the specific and cumulative impacts of local anthropogenic pressures, while disentangling them from the natural evolution processes at the same scales.

- Characterizing and understanding the rare and extreme events impacting the coastal and nearshore systems, and the resilience processes after these events.

- Improving and optimizing the already existing observation networks, together with developing methods for scale transfer.

In order to understand and predict the physical, chemical, and biological processes controlling these areas, the observation of coastal and nearshore ecosystems thus requires:

- An integrated and multidisciplinary approach (example given: a wide range of parameters mixing biological and physico-chemical properties).

- Observation sites and parameters robust enough to characterize the global evolution trends of many different coastal environments at many different time scales (e.g., diffuse and long-term changes as well as adverse consequences of extreme events).

- To take full advantage of both remote and multiple in situ techniques (from high frequency sensors to low frequency measurement campaigns) to describe a given environment.

In addition, with references to integrated systems already developed in several coastal regions (e.g., IOOS - U.S. Integrated Ocean Observing System, IMOS - Integrated Marine Observing System, COSYNA - Baschek et al., 2017,
POSEIDON - Petihakis et al., 2018), this diverse and ambitious instrumental facility also calls for:

- The implementation of coastal observation into larger scale ocean observing systems to foster the understanding and forecasting of the evolution of global ocean and anthropized nearshore zones.

- An optimal balance between the sampling of targeted regions with ocean observatories, up-to-date modeling capacities and end-user requirements.

Lastly, this approach of long-term nearshore and littoral observing systems tends to transcend academic research boundaries and significantly contribute to (i) education (academic curriculums, lifelong learning programs, outreach activities, (ii) industrial need, and (iii) public policy support (scientific mediation, coastal risk assessment, and adaptive management).

\section{THE FRENCH COASTAL OCEAN AND NEARSHORE OBSERVATION STRUCTURATION}

\section{From Local to National Integrated Systems}

Since the 1980s, according to their missions and their geographical location, certain French science-oriented public institutions have created, developed, and structured coastal observatories along metropolitan and oversea coastlines. These institutions are: CNRS-INSU: National Center for Scientific Research - National Institute for Earth Sciences and Astronomy ${ }^{1} /$ Ifremer: French Research Institute for Exploitation of the sea /IRD: National Research Institute for Sustainable Development ${ }^{3} /$ Shom: Naval Hydrographic and Oceanographic Service $^{4} /$ IGN: National Geographic Institute ${ }^{5}$ and several French Marine Universities ${ }^{6}$.

During the 1990's, CNRS-INSU designed 5-year-long National Observation Services (SNO) accreditations to federate thematically observation facilities (tools, resources, services) dedicated to earth observation. Such accredited services are motivated by the need to document the long-term changes, evolution, and variability of terrestrial systems, and to advance knowledge in these areas. Decisions to create new SNO, and to renew, evolve or abolish existing SNO, are based on a scientific evaluation organized by specialized committees including scientific experts from each French public institution with an interest in scientific observation.

SNO are provided with recurrent catalytic funding, and in return are intended to provide some services to the scientific

\footnotetext{
${ }^{1}$ http://www.insu.cnrs.fr

${ }^{2}$ wwz.ifremer.fr/en

${ }^{3}$ en.ird.fr/the-ird

${ }^{4}$ www.shom.fr/en/

${ }^{5}$ www.ign.fr/institut/en

${ }^{6} \mathrm{https}: / / \mathrm{www}$.universites-marines.fr/fr
} 
community for production and access to data. They have an obligation to implement the necessary processes to share data and metadata without any retention conditions (within the constraints imposed by international organizations).

This accreditation became a recognized label for observation structuration, leading to applications from observation teams outside the CNRS, and thus paving the way for national structuration.

\section{ILICO - The French Research Infrastructure for Coastal Oceans and Seashores}

In 2014, with the intention of fostering the structuration of the landscape of resources dedicated to research of a national scope (measurement tools, observation, modeling, simulations, etc.), the French Ministry of Higher Education, Research, and Innovation (MESRI) offered to federate the coastal, nearshore, and littoral observation services (Figure 1 and Table 1) and research communities within a national research infrastructure named ILICO (Infrastructure de Recherche Littorale et Côtière ${ }^{7}$ ). ILICO is one of the 99 research infrastructures which cover the entire spectrum of French research. Research infrastructures are strategic steering tools which aim to structure initiatives and investments made in the field of research.

The ILICO research infrastructure is dedicated to the knowledge of natural coastal and nearshore system dynamics. It mobilizes approximately 420 employees corresponding to 90 fulltime positions, and has a total annual budget (including salaries) of approximately $10 \mathrm{M} €$.

ILICO observation points (Figures 2A,B) are implemented along metropolitan and overseas French coasts, and monitor coastline dynamics, sea level evolution, physical and biogeochemical water properties, coastal water dynamics, phytoplankton composition, and the health of benthic habitats.

ILICO networks utilize a wide range of observation techniques (Figure 3 and Table 1).

\footnotetext{
${ }^{7}$ www.ir-ilico.fr
}

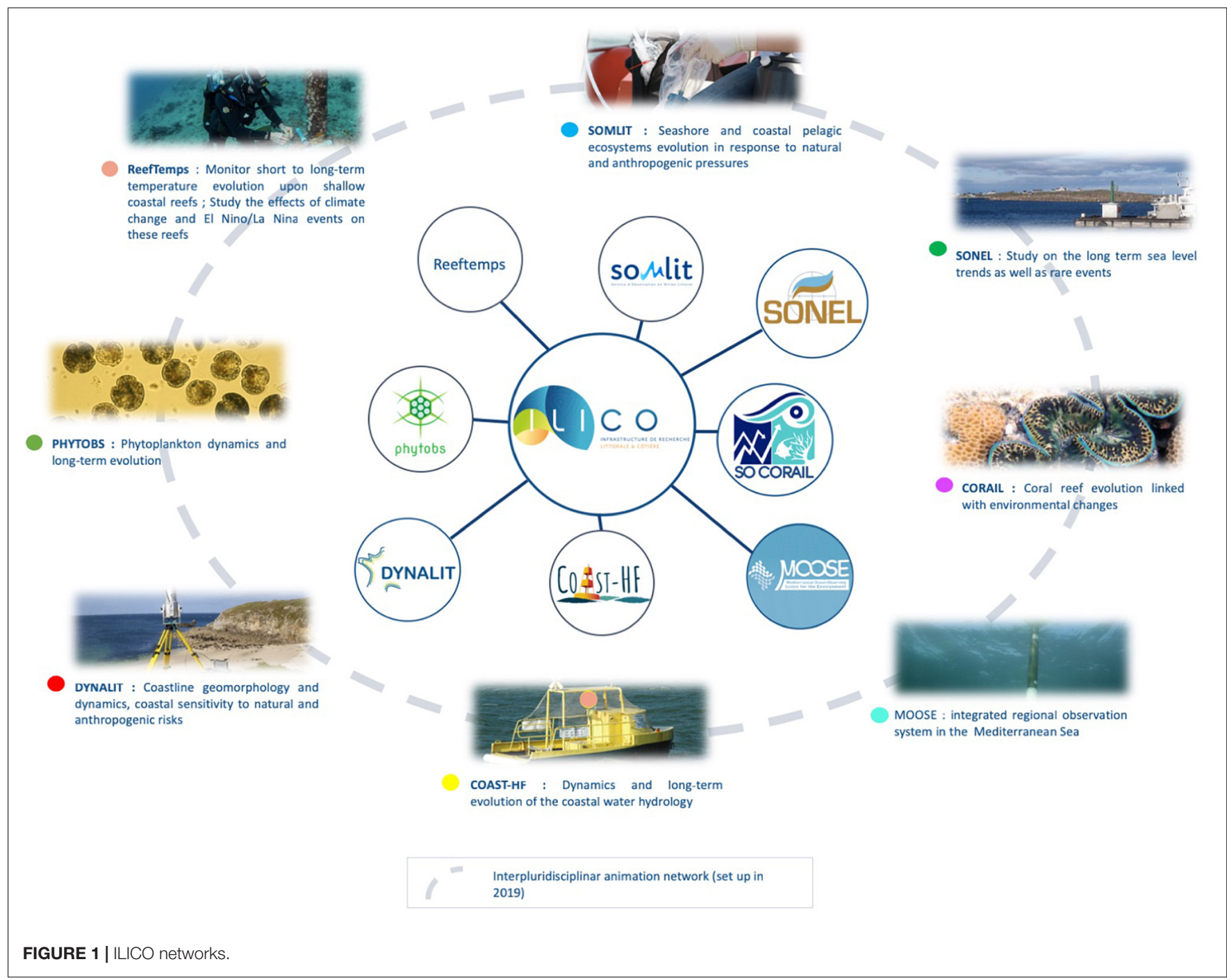


TABLE 1 | Presentation of ILICO eight observation networks.

\begin{tabular}{|c|c|c|c|c|}
\hline \multirow{2}{*}{$\begin{array}{l}\text { Network } \\
\text { (creation } \\
\text { date) }\end{array}$} & \multicolumn{3}{|c|}{ Measurement strategy } & \multirow[t]{2}{*}{ Scientific outcomes/rationale } \\
\hline & Parameters & Observation spots & Frequency & \\
\hline $\begin{array}{l}\text { COAST-HF } \\
(2016)\end{array}$ & $\begin{array}{l}\text { Conductivity/salinity; wave } \\
\text { direction, velocity and periodicity; } \\
\text { wind direction and velocity; } \\
\text { fluorescence; dissolved oxygen; } \\
\text { pH; turbidity; nutrients; } \\
\text { atmospheric pressure and humidity; } \\
\text { aerial and water temperature }\end{array}$ & $\begin{array}{l}\text { Fourteen high frequency, } \\
\text { permanent, observation } \\
\text { platforms along the French } \\
\text { coast }\end{array}$ & $\begin{array}{l}\text { The sampling frequency is } \\
\text { adapted to each of the } \\
\text { parameters (e.g., } \\
\text { 10-30 min for the physical } \\
\text { parameters; once a day for } \\
\text { the nutrients) }\end{array}$ & $\begin{array}{l}\text { By federating and managing high frequency, } \\
\text { continuous observation platforms along the } \\
\text { French coasts, COAST-HF contributes to the } \\
\text { monitoring and understanding of } \\
\text { physics-biology multi-scale coupling and to } \\
\text { detecting some extreme episodic events not } \\
\text { detected by a lower resolution (1- or 2-weeks } \\
\text { sampling intervals) monitoring approach } \\
\text { (Blain et al., 2004; Many et al., 2016) }\end{array}$ \\
\hline $\begin{array}{l}\text { CORAIL } \\
(1985)\end{array}$ & $\begin{array}{l}\text { Coral reef communities: } \\
\text { Abundance, age, biomass, } \\
\text { taxonomic diversity, mortality, } \\
\text { habitat structure, population } \\
\text { structure, demographic features. } \\
\text { Physico-chemical environment: } \\
\text { fluorimetry, nutrients, dissolved } \\
\text { oxygen, pH, chlorophyll a, water } \\
\text { pressure, salinity, temperature, } \\
\text { turbidity. }\end{array}$ & $\begin{array}{l}\text { Captures physical, } \\
\text { physico-chemical, and } \\
\text { biological evolution in time in } \\
\text { coral reef ecosystem }\end{array}$ & $\begin{array}{l}\text { For the biological } \\
\text { parameters the sampling } \\
\text { frequency is once a year or } \\
\text { once every } 2 \text { years. For the } \\
\text { physical parameters, } \\
\text { between one and four } \\
\text { times per hour with } \\
\text { automatic systems. }\end{array}$ & $\begin{array}{l}\text { CORAIL long-term monitoring captures the } \\
\text { evolution of the ecological properties of coral } \\
\text { reef ecosystems of the tropical South Pacific } \\
\text { area, as well as associated physico-chemical } \\
\text { parameters. It aims to detect, follow, analyze, } \\
\text { and model the coral reefs evolution linked } \\
\text { with environmental changes induced by } \\
\text { human activities and climate change (Galzin } \\
\text { et al., 2015; Lamy et al., 2016) }\end{array}$ \\
\hline
\end{tabular}
$\begin{array}{ll}\text { DYNALIT } & \text { Nearshore bathymetry and } \\ \text { (2014) } & \text { topography, shoreline position, } \\ & \text { pictures of the seashore, turbidity } \\ & \text { wave characteristics, currents }\end{array}$

Thirty-five coastal sites in metropolitan and oversea France covering a wide range of geomorphology (littoral systems, open bays, ria, estuary, lagoon, semi-enclosed systems, etc.), and characteristics: oligo/eutrophic ecosystems, micro/mega-tidal regimes, etc.

Cf. Table 2
PHYTOBS (2016)
Phytoplankton diversity and abundance (micro-phytoplankton, and in some places nano and pico) dissolved oxygen, $\mathrm{pH}$, temperature, salinity, turbidity, pigment, chlorophyll
Twenty-six observation sites along the French metropolitan coasts
Measure frequency: from 5 to 10 min for high frequency and from one to two times per year for low frequency
The frequency of the measurements is two times per month
To analyze the coastal geomorphological sensitivity to natural and anthropogenic risks, DYNALIT allows observation and quantification of the seashore evolution, and understanding of the morphodynamical processes. (see section "DYNALIT Network")

Cf. Table 2

Over the last decades long-term warming and increasing salinity trends have been established in the North-West Mediterranean Sea (Rohling and Bryden, 1992; Béthoux and Tailliez, 1994; Krahmann and Schott, 1998; Send et al., 1999; Béthoux et al., 2002; Rixen et al., 2005). Due to the complexity of the phenomenon at various temporal and spatial scales and its impacts on biogeochemical content (e.g., nutrients replenishment, carbon uptake), only long-term continuous observations are able to improve our knowledge on the temporal variability of the northwestern Mediterranean water changes (Somot et al., 2016) (see section "The MOOSE Network")

Long-term series on marine phytoplankton and related hydrological conditions are not only of interest in the study of phytoplankton population and community dynamics, but also on the impact of climate change on marine biodiversity (Widdicombe et al., 2010; Wiltshire et al., 2010; Hernández-Fariñas et al., 2014). PHYTOBS observations along French metropolitan coasts detected significant temporal changes in phytoplankton communities (Rombouts et al., 2019) and also contributed to highlight different environmental controls that might favor the bloom developments (Thorel et al., 2017) 
TABLE 1 | Continued

\begin{tabular}{llll}
\hline $\begin{array}{l}\text { Network } \\
\text { (creation } \\
\text { date) }\end{array}$ & Parameters & Measurement strategy & \\
\cline { 2 - 4 } & Observation spots & Frequency \\
\hline REEFTEMPS & Temperature, pressure, and & Network of temperature (and & Temperature frequency \\
$(2010)$ & sometimes pH, chlorophyll, salinity, & sometimes multiparameter) & from 1 to 30 min according \\
& waves, dissolved oxygen, turbidity & sensors in the coral reefs of the & the sites \\
& & $\begin{array}{l}\text { South Pacific Ocean; } 75 \\
\text { observation sites deployed in }\end{array}$ & $\begin{array}{l}\text { Other parameters: } \\
\text { 15-30 min }\end{array}$ \\
& & 20 countries & \\
& & Depth: from 6 to $60 \mathrm{~m}$ &
\end{tabular}

Scientific outcomes/rationale

REEFTEMPS temperature data series in the coral reefs of the Pacific Ocean are open to a wide scientific community, they may be used (i) to monitor the long-term effects of climate change and El Niño/La Niña events and their impacts on the coral reefs and associated resources, (ii) to characterize coastal upwelling, circulation, and heat balance along coral reefs, in relation to wind stress or local biological or thermal structures (Alory et al., 2006; Marchesiello et al., 2010); or (iii) to help to validate lagoon models or numerical simulations (Ouillon et al., 2005)

SOMLIT Nutrients, dissolved oxygen, $\mathrm{pH}$,

(1996) temperature,suspended particulate matter, turbidity, fluorescence, chlorophyll, salinity, particulate organic carbon, and nitrogen, $\delta^{15} \mathrm{~N}$, $\delta^{13} \mathrm{C}$, determination, numbering, and optical properties of pico- and nanoplankton classes.

SONEL Sea level, leveling height,

(2003) geocentric height, intensity of gravity field, geodetic positioning
19 observation sites located in 11 ecosystems dispatched on the French coast

Eighty-six measurement sites along metropolitan French coasts and overseas
The frequency of the measurements is two times per month

Daily and monthly mean sea level for Tide Gauges and $30 \mathrm{sec}$ for the co-located GNSS stations

The SOMLIT network measures a wide range of hydrological and biogeochemical characteristics of the surface waters once every 2 weeks. It is presented in more detail thereafter (see section "SOMLIT Network")

SONEL provides high-quality continuous measurements of sea- and land levels at the coast from tidal gauges (relative sea levels) and from GNSS geodetic techniques (vertical land motion and absolute sea levels) for studies on long-term sea level trends as well as rare events.

Initially designed for maritime navigation purposes, some of the oldest tide gauge records date back to the 18th century (e.g., Woppelmann et al., 2006). Data archeology have successfully recovered sea-level information valuable for climate studies (Testut et al., 2006; Pouvreau, 2008)
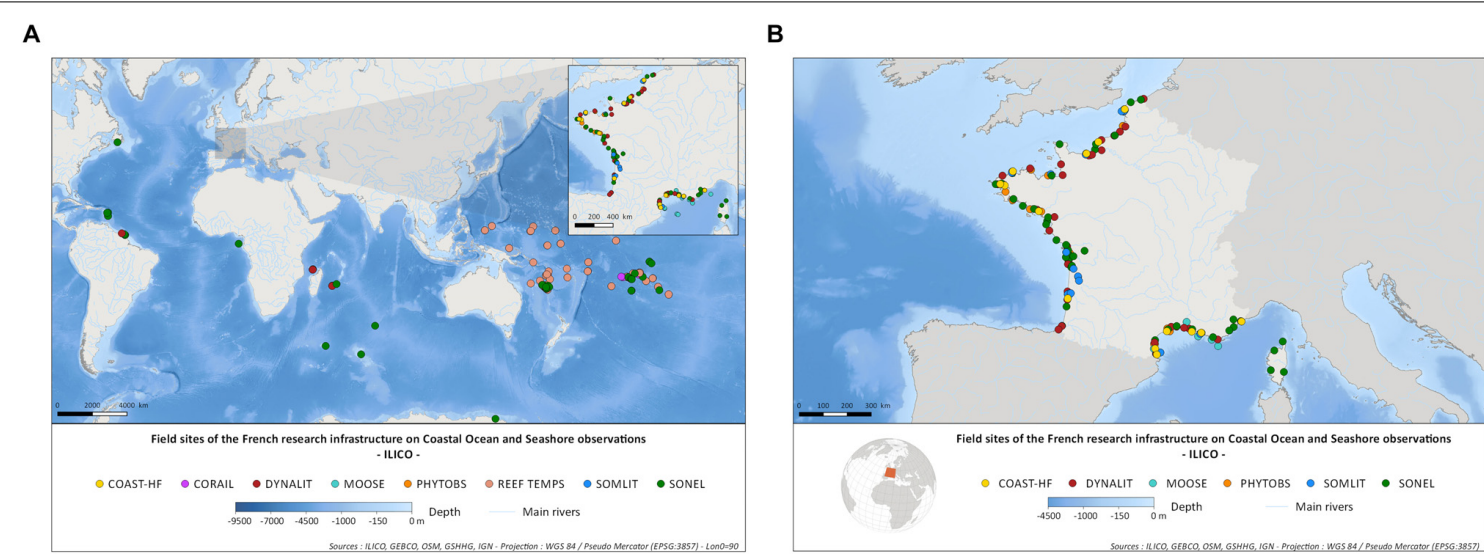

FIGURE 2 | (A) Global fields sites of ILICO observation. (B) Metropolitan fields sites of ILICO observation.

In order to meet the ambitious motivations and challenges, ILICO (started in 2016) inherited a great number of facilities and organizations, some of which were built over decades.
In addition to these observation networks, ILICO runs a scientific transversal network in charge of general scientific potential and of optimizing the use of data in high-level research projects. 


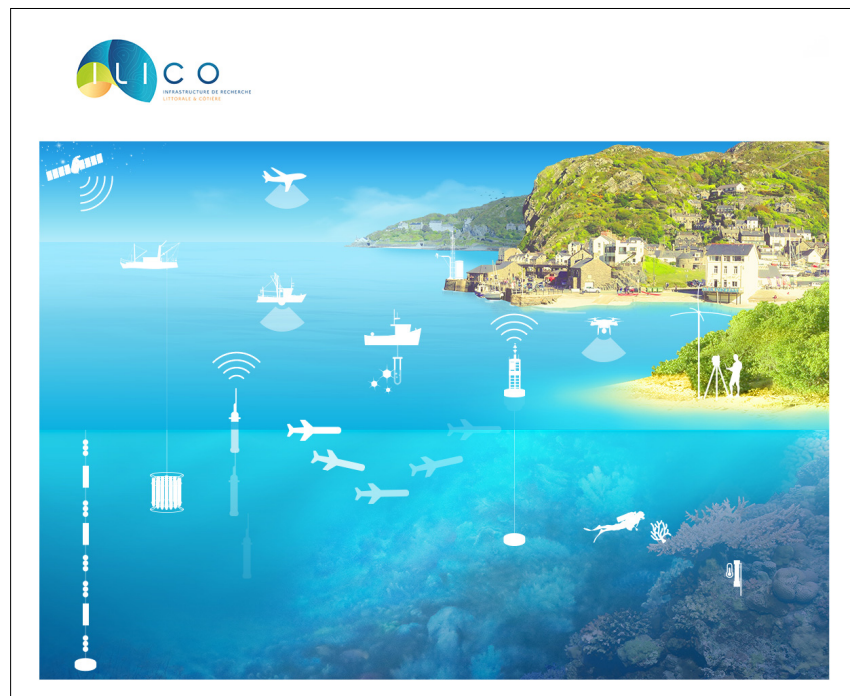

FIGURE 3 | Techniques used for coastal ocean and nearshore observation.

Observation networks, mainly pre-existing ILICO for years, have combined their unique viewpoints and strengths in order to examine the global strategy. In this paper, we would like to highlight the contributions of three networks, given their particular characteristics: (i) SOMLIT, with a homogeneous sampling strategy, (ii) DYNALIT, challenged with its heterogenous observation sites in terms of physiographic conditions and monitoring strategies, and (iii) Mediterranean Ocean Observing System for the Environment (MOOSE), laying the groundwork for an integrated observation network.

\section{SOMLIT Network}

\section{Scientific Objectives}

SOMLIT (Coastal ocean observation service - Service Observation en Milieu LITtoral) studies the long-term evolution of coastal pelagic ecosystems and seeks to determine the natural and anthropic driving mechanisms of their functioning at local and regional scales. It focuses on the hydrological, biogeochemical, and ecological characteristics of the surface waters. It also aims at providing data sets to national and international communities for research, education, and stakeholder purposes, and serves as logistic support for research and education projects.

\section{Short Description of the Observation Network}

Gathering six marine stations and laboratories at its creation in 1996, SOMLIT now observes 11 ecosystems distributed along the English Channel, the Bay of Biscay, and the Mediterranean Sea. These ecosystems cover a large range of characteristics, such as trophic status (from oligo- to eutrophic ecosystems), tidal regime (from micro- to mega-tidal regimes), geomorphology (littoral systems, open bays, ria, estuary, lagoon, semi-enclosed systems, etc.), connection to the continent, and turbidity, etc. Each ecosystem is studied thanks to one, two, or three sampling sites, with a total of 19 sites sampled along a continent-ocean gradient (when more than one site is sampled per ecosystem) (Figure 4). Sixteen parameters [temperature, salinity, $\mathrm{pH}$, dissolved oxygen, nitrate, nitrite, ammonium, phosphate, dissolved silica, suspended particulate matter (SPM), particulate organic carbon (POC), and nitrogen (PN) and their isotopic composition $\left(\delta^{13} \mathrm{C}_{\mathrm{POC}}, \delta^{15} \mathrm{~N}_{\mathrm{PN}}\right)$, chlorophyll $a$, and pico- and nano-plankton (determination, numbering, and optical properties of plankton classes)] are measured in situ or after water sampling and processing on a bi-monthly basis using standardized protocols and under quality control. In addition, water column profiles of temperature, salinity, and fluorescence are performed. More than 80 people from 13 research units belonging to 12 institutions are involved in SOMLIT.

More than 80 persons representing fifteen FullTime Equivalent (FTE) from 12 institutions (CNRS, marine universities, etc.) and 13 research units are involved in the SOMLIT.

\section{Some Key Scientific Results}

First of all, it appears that the ecosystems studied by SOMLIT are deeply sensitive to climate variability. Indeed, a study focused on the first 10 years of the SOMLIT data sets (1997-2006; Goberville et al., 2010) revealed strong correlations between regional climate and hydro-climatic characteristics (sea level pressure, wind direction and intensity, sea surface temperature, and precipitation), the coastal environment (i.e., SOMLIT historical parameters: temperature, salinity, $\mathrm{pH}$, dissolved oxygen, nutrients, SPM, POC, PN, and chlorophyll a) and two large-scale climate indexes - the Northern Hemisphere Temperature (NHT) and the Atlantic Multi-decadal Oscillation (AMO). A similar study (Lheureux et al., in preparation) performed on data sets covering two decades confirms this tight coupling between coastal environment, hydro-climatic characteristics, and climate indexes including the AMO and NHT, but also the NAO (Northern Atlantic Oscillation) and EAP (Eastern Atlantic Pattern) as well as river characteristics (flow, nutrient concentrations).

A study dedicated to POC and PN concentrations and stoichiometry compared temporal (from infra-seasonal to decadal) variability among coastal (mainly SOMLIT) and open-ocean sites and ecosystems (Talarmin et al., 2016). An overall discrimination appeared between coastal and open-ocean sites. Coastal waters usually encountered a higher seasonal variability of POC and PN concentrations and ratios as compared to open-ocean sites, and exhibited declines in POC and PN concentrations. However, (i) there were numerous local particularities, and (ii) short-term (i.e., infra-seasonal) variability was a large fraction of the temporal variability. This may highlight the role of local conditions in the variability of POC and PN concentration and stoichiometry.

A study (Liénart et al., 2017, 2018) dedicated to the origin and composition of particulate organic matter (POM) highlighted the high dominance of phytoplankton in the POM composition in the SOMLIT ecosystems, except in the Gironde estuary in which POM is mainly of terrestrial origin. Two main gradients were revealed. First, a continentocean gradient with offshore sites where POM is almost 


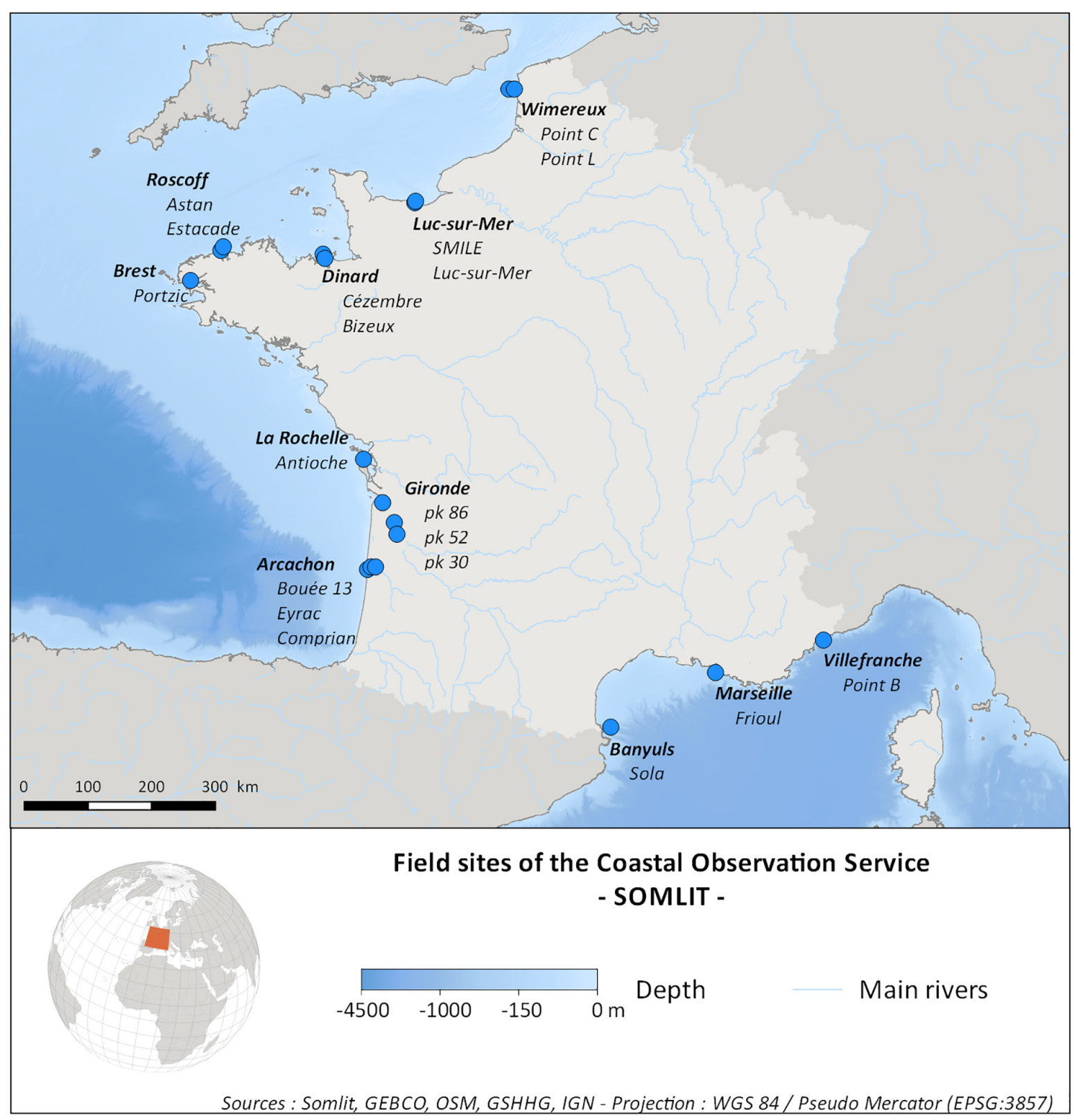

FIGURE 4 | Location of the SOMLIT sampling sites along the French metropolitan coasts.

only composed of marine phytoplankton, versus sites located close to the continent in shallower water columns where the contribution of benthic POM (seagrasses, benthic micro- and macro-algae) and/or continental POM (riverine/estuarine phytoplankton and terrestrial POM) is noticeable. Second, a gradient of ecosystem trophic-status where the POM compositions of oligotrophic ecosystems are characterized by the presence of diazotrophs. Hydrodynamics, sedimentary dynamics, and depth of the water column are the drivers of the POM composition along the former gradient, whereas nutrient availability is the main driver along the latter gradient.

\section{Discussion}

During the last two decades, SOMLIT has evolved in three directions. (1) The number of monitored ecosystems and sites has increased: Firstly, the number of study sites per ecosystem increased for some ecosystems (e.g., the Arcachon lagoon) in order to better take into account the onshore-offshore gradient for the long-term evolution of the coastal ecosystems; as well, more research teams and units joined the SOMLIT network allowing for the monitoring of a larger group and larger types of ecosystems (e.g., the bay of Seine, a large open bay). The challenge here is to develop and promote standardized protocols easily transferable to a wider community. (2) The number of parameters 
increased beyond the traditional ocean hydrology parameters; notably, stable isotope ratios of POC and PN enable researchers to take into account the large diversity of POM sources, which is specific to the coastal ocean, considering that the different sources of POM do not behave similarly regarding biogeochemical cycles and trophic transfer; also the determination and counting of pico- and nano-plankton classes allow researchers to take into account the plankton diversity, which is deeply linked with biogeochemical cycles. (3) The scientific use of the SOMLIT data sets evolved from local studies to national and international studies (e.g., the results cited above). These three directions should be maintained over the next decade and promoted within ILICO, along with robust statistic tools.

\section{DYNALIT Network}

\section{Scientific Objectives}

The primary scientific objective of SNO DYNALIT is to collect relevant, long-term, and accurate data on the physical evolution of the coast. DYNALIT aims to increase our understanding and predictive capability of coastal dynamics, in the context of increased coastal urbanization and threats by climate change, through the development of innovative numerical models. An overarching goal of DYNALIT is to support evidence-based policies and contribute to sustainable coastal risk management in the regions threatened by erosion and submersion hazards.

\section{Short Description of the Observation Network}

SNO DYNALIT, accredited by CNRS-INSU, was established in 2014 to monitor coastal change and the primary factors at play along tropical overseas and temperate metropolitan French waters. At the time of writing this paper, DYNALIT includes more than 120 researchers from 20 laboratories and 22 universities. Observations are collected at 35 coastal sites in metropolitan and oversea France (Figure 5), encompassing the three main coastal environments, namely sandy, rocky, and muddy coasts, including, e.g., open coasts, embayments, sandpits, and estuaries, with a wide spectrum of behaviors and of erosion/accretion trends. Observed parameters are primarily Digital Elevation Models (DEMs) on sandy and rocky coasts, and turbidity in estuarine environments. DEM data are collected through various means, including differential global positioning system measurements, video monitoring, structure from motion using unmanned aerial vehicles, and Lidar, while turbidity is typically measured in situ using turbidity meters. DYNALIT also collects additional environmental in situ and remotely sensed data such as shoreline position and links them with forcing factors such as incident waves, tide, and wind conditions.

\section{Some Key Scientific Results}

Climate change may cause an increase in coastal extreme events in many regions of the world (e.g., Zappa et al., 2013). In addition, rising sea levels will increase the occurrence of extreme water levels at the coast. Therefore, addressing the impact of extreme events and if and how the coast can recover is of paramount importance to improving models of flooding, erosion, and recovery and ultimately to assess coastal resilience. Addressing such short- to long-term impacts on the coast can only be achieved if long-term monitoring programs are operating on a representative range of coastal settings. A relevant example is the research that was driven by the winter of 2013/2014 during which an exceptional sequence of extratropical storms crossed the Northeast Atlantic region (Davies, 2015). According to numerical weather and wave hindcasts, that winter was the most energetic one along the Atlantic coast of Europe since at least 1948 (Masselink et al., 2016), and most of western Europe's sandy and rocky coastline was severely impacted (Castelle et al., 2015; Masselink et al., 2015; Autret et al., 2016; Burvingt et al., 2018). Masselink et al. (2016) analyzed a unique dataset of decadal, at least bimonthly surveyed, beach morphological changes along the west coast of Europe comprising sites from DYNALIT, namely Vougot, Porsmilin, and Truc Vert. The authors showed that while extensive beach and dune erosion occurred on open coasts due to offshore sediment transport, more sheltered sites experienced less erosion and one of the sites even experienced accretion due to beach rotation induced by alongshore sediment transport. Extending the same dataset to 2018, Dodet et al. (2019) showed that the recovery signature is site specific and multi-annual, with one studied beach fully recovered after 2 years, and the others only partially recovered after 4 years. On open cross-shore transport dominated coasts, simple semiempirical shoreline change models (e.g., Yates et al., 2009; Splinter et al., 2014; Lemos et al., 2018) accurately reproduce the erosion driven by the 2013/2014 winter and subsequent post-storm recovery, but they largely fail on more complex sites. This further strengthens the recent development of a new generation of reduced-complexity shoreline change models coupling cross-shore, longshore, and other processes such as sea level rise (Vitousek et al., 2017; Robinet et al., 2018), to be used to investigate, hindcast, and ultimately forecast the erosion and recovery process in more detail on a wide range of coasts.

This demonstrates that implementing monitoring programs across a wide range of representative sites with different geological settings and degrees of wave exposure, as DYNALIT does, is crucial to understand and further predict the full natural variety of coastal response and recovery. Not only do the above studies improve our understanding of storm impact and subsequent recovery, which timing and magnitude can provide a proxy measure for coastal resilience to climatic variability and change, they also motivated new research into the winter wave climate and resulting multi-decadal change in winter mean, variability, and periodicity of wave activity in the North Atlantic Ocean (Castelle et al., 2017, 2018). The strong control of certain climate indices on winter wave climate and coastal response, such as the winter NAO and the West Europe Pressure Anomaly (WEPA) north and south of approximately $52^{\circ} \mathrm{N}$, respectively, suggests that the ability of climate models to predict the winter NAO and WEPA indices a few months ahead will be crucial to anticipate coastal hazards along the Atlantic coast of Europe. 


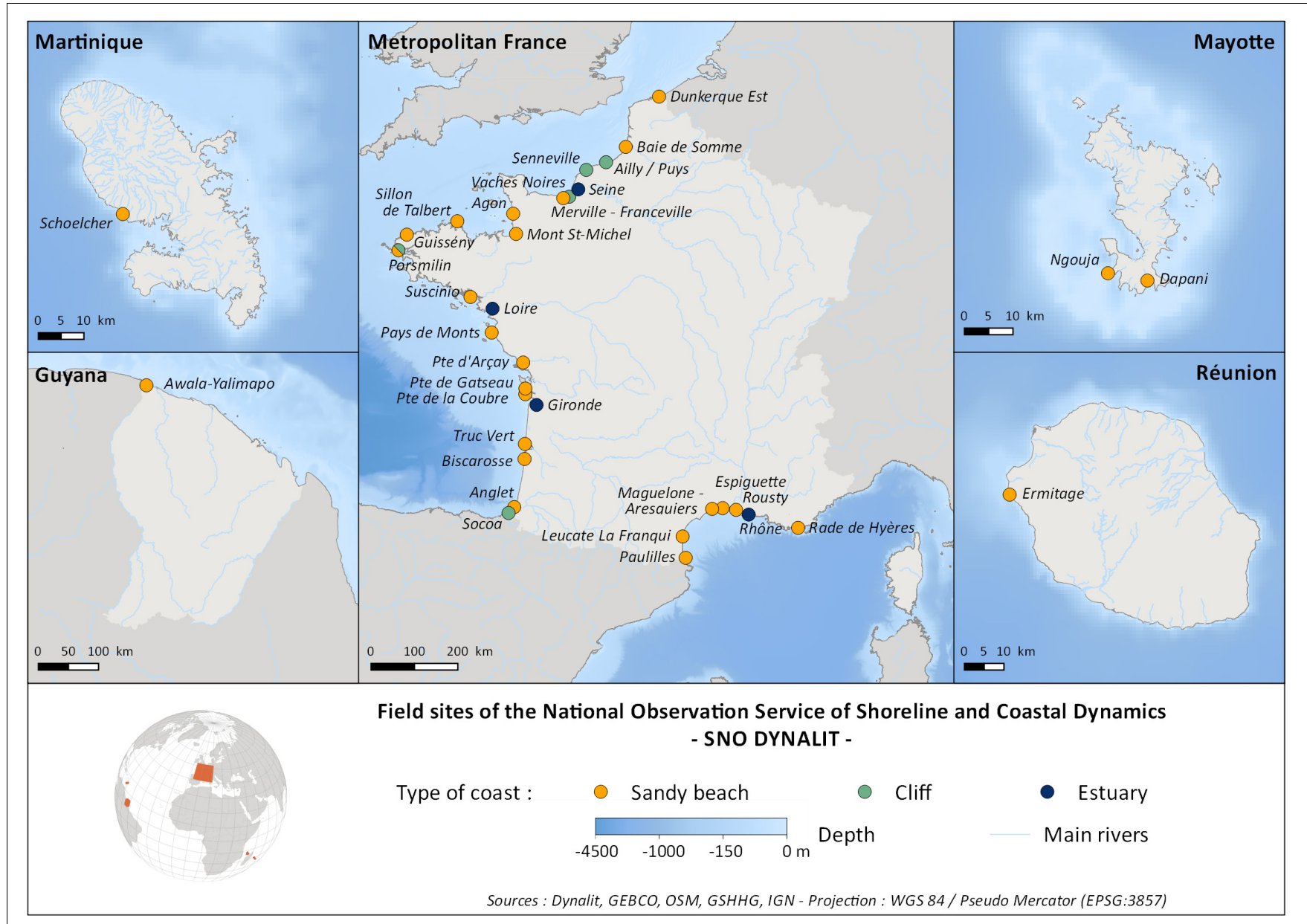

FIGURE 5 | Location map of the DYNALIT sites in metropolitan and overseas France with indication of the type of coasts.

\section{Discussion}

DYNALIT was established only 4 years ago and, except the recent studies discussed above and some common methodological developments in estuarine monitoring that were not addressed here, there has been only a little interaction and/or combination of data acquired at different sites with DYNALIT. Over the next few years, similarly to ILICO, DYNALIT will have to further encourage and develop inter-site collaborations and homogenize its monitoring strategies in order to perform more comprehensive studies on coastal response, such as that of Dodet et al. (2019). As a first step, DYNALIT is currently preparing a special issue for the Journal of Coastal Research, entitled " Coastal Evolution under Climate Change along the Tropical Overseas and Temperate Metropolitan France " in which a first synthesis of the DYNALIT monitoring programs and guidelines will be proposed. Within the next few years DYNALIT will also benefit from new means of surveying the coast. Some examples include the use of: (i) bathymetric Lidar, as while most of the DYNALIT surveys are performed dry on the intertidal domain, the subtidal domain hosts the largest sources of morphological variability, particularly along sandy coasts; (ii) satellite remote sensing which can now provide increasingly high resolution products to map the shoreline, and potentially infer the nearshore bathymetry, on large spatial scales which may close the gaps between the more precise but interspersed monitoring sites of DYNALIT. Lastly, more interactions between data and models must also be encouraged.

\section{The MOOSE Network Scientific Objectives}

Slow and irreversible changes are occurring in Mediterranean waters - including the warming of deep waters, an increase in anthropogenic carbon dioxide, and acidification. Such factors are inducing changes in both deep waters and marine habitats as a whole. Despite intensive research efforts undertaken in the Mediterranean Sea over more than a century, an integrated view of its evolution, in the framework of climate change and anthropogenic pressures is still lacking. In this context, the Mediterranean Ocean Observing System for the Environment (MOOSE) has been set up as an interactive, distributed, and integrated observatory of the North-Western Mediterranean Sea to detect and identify long-term environmental anomalies. It includes both longterm monitoring and near real-time measurement capabilities 
concerning river inputs, atmospheric deposition, and in situ marine measurement capabilities.

\section{Short Description of the Observation Network}

The MOOSE Network was initiated in 2008 and built during the five following years. Since 2015 this organization has developed into a unique multidisciplinary network (Figure 6) that pools efforts and initiatives to converge on best practices, and supports common measurement standards (Figure 7).

The personnel assigned to these operations represent five FTE posts for researchers and 7.6 FTE posts for engineers and come from 10 different research institutions. Around 5-10 Ph.D. students have been regularly involved in the processing and analysis of data from the MOOSE network.

MOOSE is built as an interactive, distributed, and integrated observatory, based on a multisite network of permanent continental, shelf, shelf-break, and deep-sea stations, and is able to detect and monitor seasonal and inter-annual variability, as well as the impact of extreme events that control fluxes and budgets in the marine environment. It combines Eulerian observatories (moorings, radars, hydrological stations) and autonomous mobile platforms (gliders, profiling floats). The MOOSE network aims to acquire and provide the Essential Ocean Variables - EOV necessary to observe the variability of physical-biogeochemical and biological processes sensitive to climate change and anthropogenic pressure (Table 2 and Figure 7).

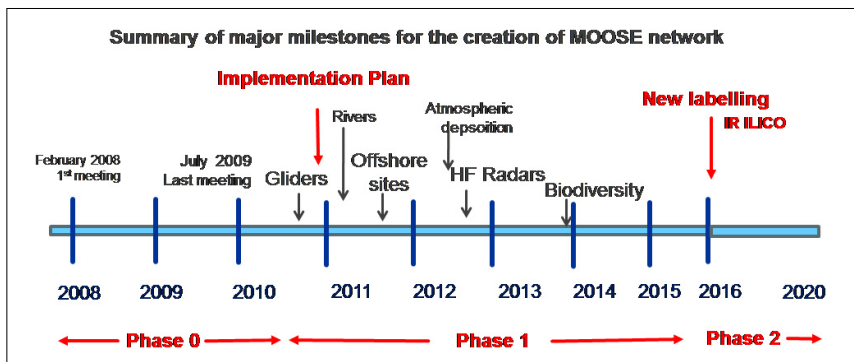

FIGURE 7 | Summary of major milestones and MOOSE phases.

The approach developed here aims to be more innovative compared to the last decade of programs being more focused on biogeochemistry and natural variability rather than on ecosystems, biodiversity and anthropogenic change.

\section{Some Key Scientific Results}

First, information on water mass distribution and deep water formation during winter has been collected using both the glider endurance lines and Eulerian moorings. The most important results concern the mesoscale circulation of the northern gyre, with a better characterization of (1) the variability of deep water formation processes (Houpert et al., 2015), (2) submesoscale processes (Bosse et al., 2015, 2016; Damien et al., 2017),

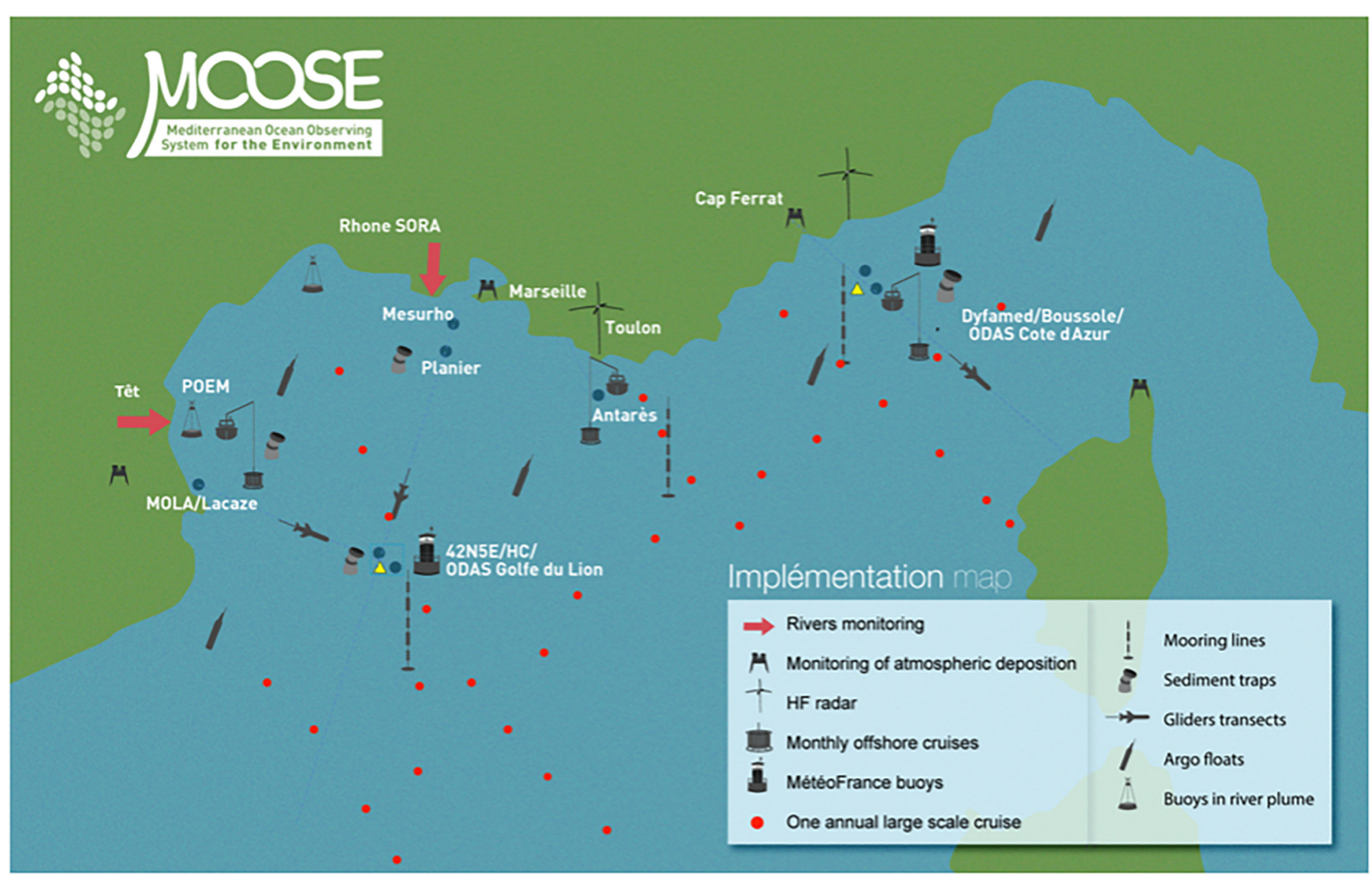

FIGURE 6 | Implementation map of the MOOSE network. 
TABLE 2 | List of platforms and parameters involved in the MOOSE network.

\begin{tabular}{|c|c|c|c|c|c|}
\hline & Platforms & Strategy & Parameters & $\begin{array}{l}\text { Sampling } \\
\text { frequency }\end{array}$ & Data transfer \\
\hline \multirow[t]{2}{*}{$\begin{array}{l}\text { Lagrangian marine } \\
\text { monitoring }\end{array}$} & Gliders & $\begin{array}{l}\text { Two transects } \\
\text { T00 Nice-Calvi } \\
\text { T02 Marseille- } 42^{\circ} \mathrm{N}\end{array}$ & $\begin{array}{l}\text { Temperature, salinity, oxygen, } \\
\text { fluorescence, turbidity }\end{array}$ & Nine transects/year & $\begin{array}{l}\text { Real time and } \\
\text { delayed time }\end{array}$ \\
\hline & HF Radars & $\begin{array}{l}\text { Two radars } \\
\text { Toulon Nice }\end{array}$ & Surface current - wave & $\begin{array}{l}\text { Hourly } \\
\text { measurements }\end{array}$ & $\begin{array}{l}\text { Real time and } \\
\text { delayed time }\end{array}$ \\
\hline \multirow[t]{9}{*}{ Eulerian marine monitoring } & Mooring LIONCEAU & $0-2,500 \mathrm{~m}$ & Temperature, salinity, oxygen, current & $\begin{array}{l}\text { Hourly } \\
\text { measurements }\end{array}$ & Delayed time \\
\hline & Mooring DYFAMED & $0-2,500 \mathrm{~m}$ & $\begin{array}{l}\text { Temperature, salinity, oxygen, current, } \\
\text { particle flux (mass, carbon, nitrogen) }\end{array}$ & $\begin{array}{l}\text { Hourly } \\
\text { measurements }\end{array}$ & Delayed time \\
\hline & Mooring LION & $0-2,500 \mathrm{~m}$ & $\begin{array}{l}\text { Temperature, salinity, oxygen, current, } \\
\text { particle flux (mass, carbon, nitrogen) }\end{array}$ & $\begin{array}{l}\text { Hourly } \\
\text { measurements }\end{array}$ & Delayed time \\
\hline & Mooring Laccase-Duthiers & $0-2,500 \mathrm{~m}$ & $\begin{array}{l}\text { Temperature, salinity, oxygen, current, } \\
\text { particle flux (mass, carbon, nitrogen) }\end{array}$ & $\begin{array}{l}\text { Hourly } \\
\text { measurements }\end{array}$ & Delayed time \\
\hline & Mooring Planier & $0-1,000 \mathrm{~m}$ & $\begin{array}{l}\text { Temperature, salinity, oxygen, current, } \\
\text { particle flux (mass, carbon, nitrogen) }\end{array}$ & $\begin{array}{l}\text { Hourly } \\
\text { measurements }\end{array}$ & Delayed time \\
\hline & $\begin{array}{l}\text { DYFAMED: research } \\
\text { vessel - CTD-water } \\
\text { collection - plankton net }\end{array}$ & $\begin{array}{l}\text { One oceanic site } \\
0-2,500 \mathrm{~m}\end{array}$ & $\begin{array}{l}\text { Temperature, salinity, oxygen, } \\
\text { Underwater Video Profiler, nutrients, } \\
\text { CO2, flow cytometer, phyto and zoo } \\
\text { communities }\end{array}$ & Monthly cruises & $\begin{array}{l}\text { Real time and } \\
\text { delayed time }\end{array}$ \\
\hline & $\begin{array}{l}\text { ANTARES: MOLA: research } \\
\text { vessel - CTD-water } \\
\text { collection - plankton net }\end{array}$ & $\begin{array}{l}\text { One oceanic site } \\
0-2,500 \mathrm{~m}\end{array}$ & $\begin{array}{l}\text { Temperature, salinity, oxygen, } \\
\text { Underwater Video Profiler, nutrients, } \\
\mathrm{CO}_{2} \text {, flow cytometer, phyto and zoo } \\
\text { communities }\end{array}$ & Monthly cruises & $\begin{array}{l}\text { Real time and } \\
\text { delayed time }\end{array}$ \\
\hline & $\begin{array}{l}\text { MOLA: research vessel - } \\
\text { CTD-water collection - } \\
\text { plankton net }\end{array}$ & $\begin{array}{l}\text { One oceanic site } \\
0-2,500 \mathrm{~m}\end{array}$ & $\begin{array}{l}\text { Temperature, salinity, oxygen, nutrients, } \\
\mathrm{CO}_{2} \text {, flow cytometer }\end{array}$ & Annual cruises & $\begin{array}{l}\text { Real time and } \\
\text { delayed time }\end{array}$ \\
\hline & $\begin{array}{l}\text { MOOSE-GE: research } \\
\text { vessel - CTD-water } \\
\text { collection - plankton net }\end{array}$ & $\begin{array}{l}\text { One oceanic site } \\
0-2,500 \mathrm{~m}\end{array}$ & $\begin{array}{l}\text { Temperature, salinity, oxygen, } \mathrm{CO}_{2} \text {, } \\
\text { nutrients, flow cytometer, pigments }\end{array}$ & $\begin{array}{l}\text { Monthly cruises, } \\
\text { real time and } \\
\text { delayed time }\end{array}$ & $\begin{array}{l}\text { Real time and } \\
\text { delayed time }\end{array}$ \\
\hline \multirow{5}{*}{$\begin{array}{l}\text { Monitoring at the } \\
\text { atmosphere/continent/sea } \\
\text { interfaces }\end{array}$} & Rhone river & One site & $\begin{array}{l}\text { Flow rate, suspended matter, organic } \\
\text { and inorganic nutrients, trace metal }\end{array}$ & Daily collection & Delayed time \\
\hline & Têt river & One site & $\begin{array}{l}\text { Flow rate, suspended matter, organic } \\
\text { and inorganic nutrients, trace metal }\end{array}$ & Daily collection & Delayed time \\
\hline & $\begin{array}{l}\text { Cap Ferrat (atmospheric } \\
\text { deposition) }\end{array}$ & One site & $\begin{array}{l}\text { Particle flux, organic and inorganic } \\
\text { nutrients, trace metal, meteorology }\end{array}$ & $\begin{array}{l}\text { Deposition: } \\
\text { 2/month } \\
\text { Rain event }\end{array}$ & Delayed time \\
\hline & $\begin{array}{l}\text { Frioul (atmospheric } \\
\text { deposition) }\end{array}$ & One site & $\begin{array}{l}\text { Particle flux, organic and inorganic } \\
\text { nutrients, trace metal, meteorology }\end{array}$ & $\begin{array}{l}\text { Deposition: } \\
\text { 2/month } \\
\text { Rain event }\end{array}$ & Delayed time \\
\hline & $\begin{array}{l}\text { Cap Béar (atmospheric } \\
\text { deposition) }\end{array}$ & One site & $\begin{array}{l}\text { Particle flux, organic and inorganic } \\
\text { nutrients, trace metal, meteorology }\end{array}$ & $\begin{array}{l}\text { Deposition: } \\
\text { 2/month } \\
\text { Rain event }\end{array}$ & Delayed time \\
\hline
\end{tabular}

and (3) quantification of shelf-slope mass balance exchanges (Durrieu de Madron et al., 2013).

New information on the dissolved oxygen variability in the North-Western Mediterranean Sea has been obtained, predicting that the lower intensity of winter convection could potentially lead to hypoxia in intermediate and deep layers with a substantial impact on marine ecosystems (Coppola et al., 2018).

High resolution sampling in the Rhone and Têt rivers, with monthly and high-resolution flood sampling of particulate trace metals (PTM) in both rivers, allows the production of highly realistic dissolved and particulate matter budgets which can further be broken down into their natural and anthropogenic counterparts (Dumas et al., 2015; Sadaoui et al., 2016).
Moreover, MOOSE has included standardized methods to quantify plankton (mainly zooplankton) and particles in its observation network at scales that match those of the physical variations. For example, trophic links between phytoplankton and zooplankton were studied in 2013 in a deep convection zone of the western Mediterranean Sea (Hunt et al., 2017). This study highlighted that in spring phytoplankton the average contributions to zooplankton biomass by pico-, nano-, and micro-phytoplankton were 42,42 , and $20 \%$, respectively.

In parallel, several optical and imaging techniques are used to increase the spatial and temporal coverage of biological observation. These methods, while having less taxonomic resolution than microscopic counts, allow for a 
rapid determination of plankton and particle community size distributions [Underwater Video Profiler (UVP), Picheral et al., 2010]. In the Gulf of Lion, UVP data combined with net samples enabled the investigation of the impacts of deep-water convection on the biology of the gulf, suggesting an enhancement of energy transfer to higher trophic levels and organic matter export in the area (Donoso et al., 2017). Finally, consistent deployments of the UVP in the Mediterranean Sea, combined with drifting sediment trap data from over the last two decades, led to the first assessment of carbon export at the basin scale level (Ramondenc, 2017). All of the above examples show the great potential of coupling advance imaging and optical methods with more "traditional" techniques in order to better understand the tight coupling between physical and biological mechanisms in the Mediterranean Sea.

\section{Discussion}

Employing ILICO ambitions on another scale, the MOOSE network is creating a solid and transparent organization that can provide operational services for the timely, continuous, and sustainable delivery of high-quality environmental data and informational products related to the northwestern Mediterranean environment. Through MOOSE, the French Mediterranean community is now able to have a permanent monitoring system of ocean dynamics covering coastal and open ocean areas. MOOSE also provides a large flux of real-time data to facilitate validation of operational oceanographic models. With many years of research lying ahead for the MOOSE project, it is expected that the system will have an impact on marine science and policy in both the short- and long-term. In terms of marine observation, it is likely that the team's delivery of products, such as measurements and indicators of change and impact, will be widely used for policy decisions. These could potentially range from energy and pollution control, to fisheries quota determinations.

Like ILICO, the MOOSE project is not intended to develop sensors and new technologies, but the observation system must be ready to host sensors (according to the scientific needs) and to guide their development or integrate them when they are sustained.

For the next step, MOOSE, together with ILICO, will oversee the implementation of new parameters and platforms according to their readiness levels, allowing the timely implementation of components that are already mature, while encouraging innovation and formal efforts to improve readiness and build capacity. Moreover, it seems crucial to better structure the relationship between the coastal system, which is ideal to observe anthropogenic impact, and the open ocean system, a perfect area for climate change issues due to the space and timescales of the processes studied.

\section{DISCUSSION AND RECOMMENDATIONS}

\section{Discussion}

ILICO has a wealth of significant contributions from constituent networks in terms of implementation and standardized monitoring strategies, the development of new parameter collection techniques, new sensors and technology data use, inter-site collaboration, and a connection to wider communities and end-users.

\section{Added Value of ILICO Governing body-wise}

Regrouping various fundamental observatory networks, ILICO made it possible to facilitate the individual organization and governing bodies of each. Some mandatory committees have been pooled between certain networks and ILICO, such as the international scientific council, which provides a global vision of the scientific interactions between the networks and the international community. Whereas financial and strategic discussions used to be conducted at individual levels, the interinstitution committee brings together the directorates of the organizations involved in ILICO to discuss the human and financial resources put in place by the various authorities (Figure 8, governance).

\section{Scientific emulation-wise}

Each of ILICO's research teams are responsible for the scientific valorization of their collected data. However, ILICO participates in the scientific outreach of the community via a network representative of the entire coastal ocean and nearshore scientific community. This scientific transverse outreach network can be seen as a forum: (i) for the scientific community involved with the observation networks, (ii) for prospective scientific reflection concerning the observation and understanding of the functioning of the nearshore and littoral environment, (iii) for cross-cutting questions to elementary networks, (iv) for expertise, reflection, and proposals on specific requests of ILICO or any related organizations, and $(\mathrm{v})$ for reflection and possible structuring of new observation networks.

An example of a collective brainstorming event was the EVOLECO (ECOsystem EVOLution) symposium, whose objective was to draw up an inventory of the long-term evolution of coastal ecosystems (through the study of a 10-year time series from ILICO's elementary observatory) and to identify the associated forcings and processes. Two workshop needs emerged: (i) Comparison of the different statistical tools implemented on the long data series of the different networks, and (ii) the origin of the discrepancies observed between the 1990s and the 2000s on sets of parameters acquired by several networks.

In addition to defining scientific hot spots and super sites, the co-localization elementary networks acquisition also allows the sharing of:

- Scientific parameters: for example, the SONEL water levels could directly be used for coastline monitoring by DYNALIT.

- Measurement tools: for instance, the sea state monitoring camera makes it possible to monitor the evolution of some benthic habitats.

\section{Data dissemination strategies-wise}

The main objective of an observation service is to provide relevant, reliable, and qualified data on a studied scientific 
Strategic level:

\section{ILICO Governance Organization}
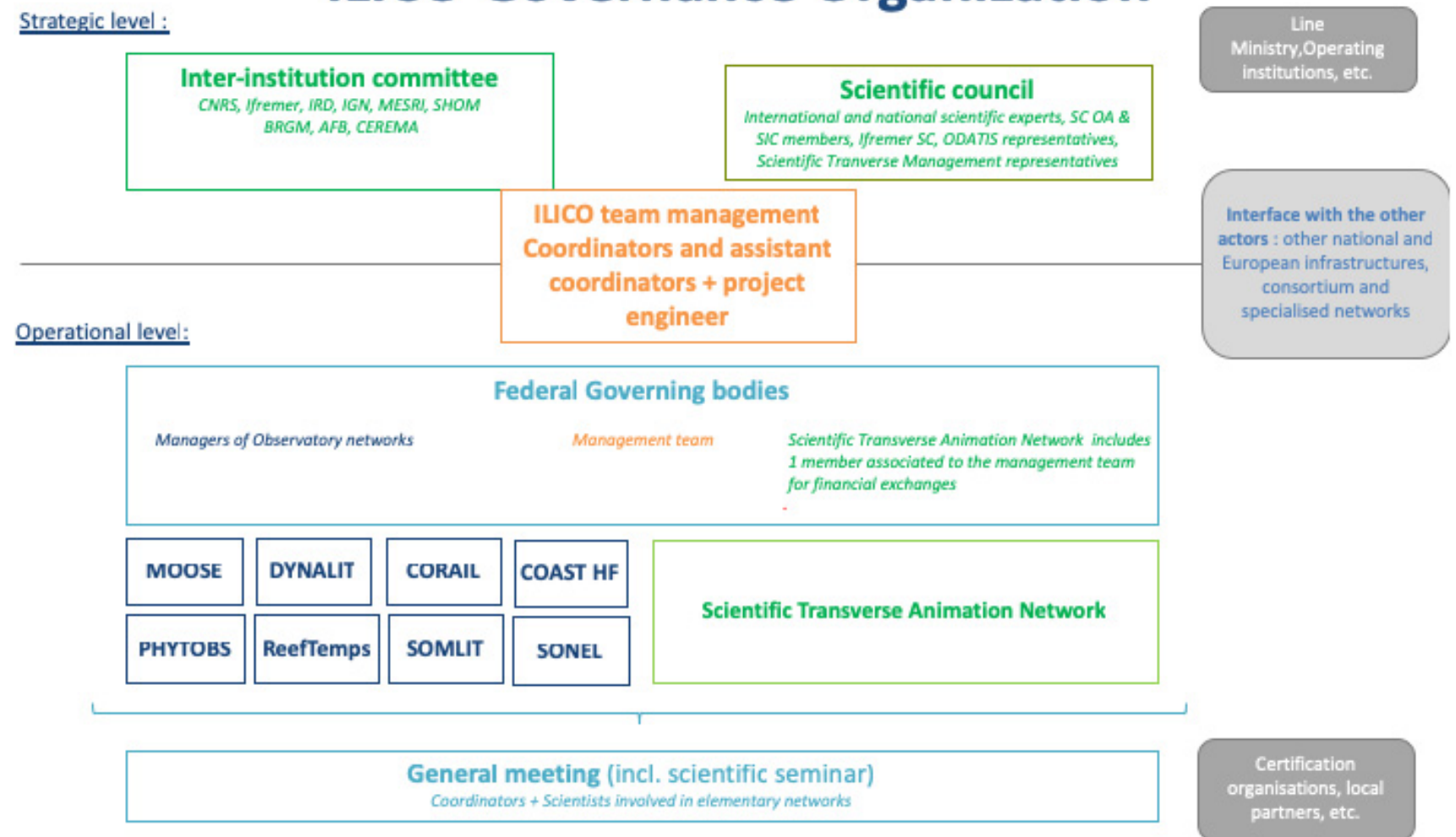

Coordinators + Scientists invoived in elementary networks

Certification

organisations, local

partners, etc

FIGURE 8 | ILICO governance organization.

phenomenon. Furthermore, data have to be shared with the wider scientific community and other end-users.

Early on, ILICO's observation networks developed individual or mutualized strategies and data infrastructures to quickly share and disseminate these observation measurements and products, with respect to the INSPIRE Directive from the European Commission (Directive 2007/2/CE of European Parliament and Council, March 14, 2007), and in the spirit of "open data" (Hocdé and Fiat, 2013). The data management of observation systems has significantly evolved in the last $10-15$ years with the implementation of shared information systems, the adoption of standards, specifications, and guidelines, and the development of interoperable technologies and web services, etc. In a context where pre-existing networks had heterogenous developments in terms of interoperability, ILICO promotes the adoption and use of the best practices within FAIR guiding principles for scientific data management (Findable, Accessible, Interoperable, and Reusable) (Wilkinson et al., 2016) and transfer of documentation into a Data Management Plan (DMP) with a shared and common metadata infrastructure, in collaboration with the national research data infrastructure SYSTEME TERRE and its specific interface dedicated to Ocean DATa Information and Services (ODATIS) to provide new services and products through a national portal in accordance with European standards.

Members of ILICO are also involved in several panEuropean initiatives and numerical infrastructures (SeaDataNet and SeaDataCloud, EMODnet, Copernicus Marine Environment Monitoring Service, etc.) and other regional data web portals (AODN, IMOS, etc.). The intersection of all these data sources, combined with the expertise of ILICO scientists, will provide new added-value services and products.

\section{Complementary Approaches of Spatial Coverage}

ILICO elementary observatories were deployed following three major types of spatial strategies: the first type is a regional pattern that aims at revealing the spatial dynamics of the observed processes; the second type involves sampling a range of sites that are representative of different types of dynamics; the third type involves sampling a range of sites with different gradients of drivers and/or functioning.

(1) Studying spatial (as well as temporal) dynamics: This goal requires studying a spatial distribution adapted to spatial dynamics, while the sampling strategy must be homogeneous along the different sites. Within ILICO, the SONEL observatory for sea level, the MOOSE regional observatory of the Mediterranean coastal zone, the REEFTEMPS and CORAIL observation networks in the Pacific, and the PHYTOBS observatory for phytoplankton were conceived in this way. Within these networks, singlepoint observations generally have little value, but the intercomparing, or spatial combination, of observations at 
different points brings more scientific value to the data. It allows for the building of a reference to which individual observations may be compared, to help distinguish local from global effects, to study spatial dynamics such as the propagation of a phenomenon, and to build regional diagnoses over the whole observed region.

(2) Studying independent, representative examples of sites: Within ILICO, the high-frequency automatic sampling platforms Coast-HF and the coastline dynamics observatory DYNALIT both follow this strategy: each observation site illuminates the functioning of local dynamics. The comparison of two different sites in the network makes sense only if these sites have comparable physiographic properties. The combination of all observation sites hardly draws a regional picture, and calculating an overall average, for instance, may not make sense. However, data from a sampled site may help understand the processes at work in a different site, not sampled, but with comparable physiographic conditions.

(3) Studying sample sites along gradients: Within ILICO, the SOMLIT observatory of water properties, some highfrequency automatic sampling platforms from COAST$\mathrm{HF}$, and some PHYTOBS sites are designed in such a way. Sampling sites and (eco)systems are selected within gradients of mechanisms like climate, tidal regimes, trophic regimes, geomorphology, turbidity, continental influence, etc. It allows a better identification and even quantification of the role of often interconnected mechanisms in the functioning and long-term change of (eco)systems.

These three types of spatial strategies are not fully exclusive: sampling sites typical of local dynamics may also be within the gradients of different mechanisms. Thus, selected sites can have local, regional, or large-scale interest, depending on the overall spatial sampling strategy. The challenge of ILICO is then to facilitate the articulation of scales from local to global.

\section{An Ongoing Europeanization}

Because ocean observations call for an integrative approach that overcomes national borders, ILICO has been designed to promote international collaborations, and more particularly a European structuration of coastal and nearshore observation efforts.

Thus, while the role of Member States remains central in developing and financing research infrastructures, the European Union plays an important part in supporting infrastructure, fostering the emergence of new facilities, opening up broad access to national and European infrastructures, and making sure that regional, national, European, and international policies are consistent and effective. It is not only necessary to avoid duplication of efforts and to coordinate and rationalize the use of the facilities, but also to pool resources so that the Union can also acquire and operate research infrastructures worldwide.

Ocean observation data life cycles can benefit from many European initiatives supported by the Directorate-General (DG) Mare (EMODnet), the DG Environment (Marine Strategy Framework Directive), the DG Grow (Copernicus
Marine Services), and the DG Research and Innovation, mainly through Framework Programs (FP) for research and technological development.

The recent approach to research infrastructures by the European Framework Programs for research and technological development has made remarkable progress with the implementation of the European Strategy Forum on Research Infrastructures (ESFRI) roadmap that identifies vital new European Research Infrastructures for the next 10-20 years, integrates and opens national research facilities, and develops e-infrastructures underpinning a digital European Research Area. The networks of research infrastructures across Europe strengthen its human capital base by providing world-class training for a new generation of researchers and engineers and promoting interdisciplinary collaboration.

As far as marine sciences are concerned, the FP/Infrastructure involves support Research Infrastructures such as research vessels (Euro fleets projects), the Argo floats program (Euro ARGO), the European Marine Seas Observatory (EMSO), and the European Marine Biological Resource Centre (EMBRC).

In the field of coastal observation, the European Union has financed two projects: JERICO - Joint European Research Infrastructure for Coastal Observation (FP7 project under grant agreement No. $n^{\circ} 262584$ Project coordinator: Ifremer, France 2007-2013) and JERICO-NEXT (H2020 project under grant agreement No. 654410 Project coordinator: Ifremer, France 2015-2019, Farcy et al., in preparation). A part of ILICO lies within the thematic scope of JERICO and JERICO-NEXT. The next step is to propose a permanent, sustained, European Observation Infrastructure for the coastal and nearshore marine environment, to be included in the ESFRI Roadmap and with respect to the emerging European Ocean Observing System, EOOS, an inclusive voluntary federation of diverse ocean observation and monitoring communities. Accredited by the French ministry for higher education and research, the ILICO infrastructure would be, entirely or in part, a component of this European infrastructure.

The aim of this European Infrastructure would be to provide one integrated system that can deliver information on coastal and shelf seas across three key application areas: marine ecosystem health, operational services, and climate. It is based on multi-platform and integrated approaches, in the continuity of the JERICO and JERICO-NEXT projects, and will be driven by science and societal needs and impacts. The European Infrastructure will also aim at filling the two following current "gaps": (1) interface with the open ocean and (2) the land-sea continuum, and lead the coastal ocean observing community in growing an integrated, responsive, and sustained European observing system.

\section{Recommendation - Coastal Ocean and Nearshore Observation 10 Years From Now \\ Scientifically Oriented Observation Strategies}

When designing a long-term observation system, one may wonder how the research questions will evolve over the 
next decade. When developing ILICO's strategy based on long-term parameter observations, we expect most of these questions still to be relevant 10 years from now. However, depending on the evolution of global change, new questions about systems resilience and adaptation could be addressed and new communities and end-users could be interested in ILICO data. In the coming years, ILICO will develop adaptation skills and foster cross-disciplinary research and trans-existing network interactions (for example, the understanding of longterm physical evolution of the morphological aspects of the coast in relation with the evolution of sea level.) in order to increase its robustness.

\section{Technical and Methodological Issues/Innovation Trends}

In the coming years, progress regarding observation strategies will emerge from:

\section{Auto-adaptive abilities}

In the next decades temporal and spatial resolutions of data acquisition will certainly address the issue of fitting the high spatial and temporal scales of the processes involved in coastal dynamics. Future sensors and platforms will enable one to autoadapt temporal and spatial sampling depending on external parameters, with the aim, for example, of acquiring data during extreme/rare metrological events.

The use of archival data and data-mining will be extended. For example, currently the estimation of the change in global sea level rise over the last century strongly depends on a small set of very long-term sea-level time series. It is important to take advantage of the mass of information that was collected in the past and which lies dormant in a number of French archives.

\section{A sober use of resources (including human resources)}

Constraint being a great source of innovation, one can expect that raising environmental concerns will generate a new generation of sensors and methods more sustainable and creating less damage to nature.

Furthermore, as previously described, most of the elementary observatories require high human-resources. Some new techniques will have to be developed in order to optimize staff hours and costs, so that financial support could guarantee all human skills and expertise when necessary.

\section{Strong connections (to real-time communications access, to other scientific communities, to end-users)}

Real-time acquisition could be of great interest in order to limit the step of data recovery. Furthermore, in the perspective of making the observatories more up front and modeled as an 'alert system' rather than the present registering systems, the coastal ocean and nearshore observation system must develop a real-time data connection. The real time survey will make these systems act more as an alert network that will inform of any ongoing change and notify scientists and stakeholders earlier so they may make rapid decisions regarding specific monitoring and early conservation. This will require strong interoperability and standardization of systems and will also raise some issues about data validation and ownership.
Finally, possible future trajectories of ecosystems have to be identified for sustainable ecosystem management. For that, predictive models are needed. Long-term data sets are precious data sets for building and testing such models. Thus, a close relationship between long-term data providers and predictive modelers should be encouraged, as well as co-construction with end-users in order to maximize their impacts.

\section{How Coastal Ocean and Nearshore Observation Can Contribute to a Better Management of Coastal Zones}

While ILICO's infrastructure is a science-based initiative motivated by academic research and purposes, it seems increasingly likely that, in the coming years, ILICO will tend to develop more operational services dedicated to the better management of coastal zones.

Coastal science fosters the resilience of coastal communities by anticipating hazards to human and ecosystem health, safety, and welfare. Accelerating coastal changes advocate for the increased accuracy and precision of predictions of future conditions at global, regional, and local spatial scales and on decadal, annual, and event time scales. The ILICO research collaborations crossing the broadest range of disciplines and coastal landscapes are ideally positioned to help meet these future challenges.

For the next decade, with ILICO becoming fully integrated and operational, observations should be able to guide policy decisions and reduce the risks to coastal communities from natural hazards and climate change, notably by:

- Giving an accurate picture of the coastal ocean state for stakeholders - can help for coastal management (for example: periods of harmful algal blooms, hydrodynamical conditions for future public/private infrastructure projects, evaluation of potential - renewable - energy).

- Contributing to the management and adaptation strategies of extreme events.

- Enhancing observational data assessment and integration to models in order to deliver long-term trend management and forecast.

\section{CONCLUSION}

ILICO, the French initiative for adding value to scattered existing institutional coastal ocean and nearshore observatories and observation initiatives, is an innovative, adaptable, and inclusive infrastructure. Such an organization enables efficient multiinstrument monitoring (through mutualization of instruments and best practices) and fit-for-purpose developments connected to scientific communities.

In the context of increasing and pressing needs for ocean information (for example: United Nations Sustainable Development Goal 14), ILICO, as a science driven infrastructure, has a growing role to play in underpinning nearshore economic activities, while ensuring the protection of coastal environments. 
This could be achieved by contributing to:

- Understand environmental and economic pressures on our coasts.

- Produce and deliver nearshore and coastal information to support blue growth and sustainable development.

- Raise societal awareness so as to become a public utility by 2030 .

Over the next decades, ILICO will keep promoting better coordinated and sustained coastal ocean observing, and the study of ocean variables relevant to society and the global ecosystem. To do so, a fruitful gap analysis could address missing observations, missing data, sustainability gaps as well as technology gaps, but first and foremost, European and international collaborations need to be built.

\section{REFERENCES}

Alory, G., Vega, A., Ganachaud, A., and Despinoy, M. (2006). Influence of upwelling, subsurface stratification, and heat fluxes on coastal sea surface temperature off southwestern New Caledonia. J. Geophys. Res. 111, 1-9. doi: 10.1029/2005JC003401.

Autret, R., Dodet, G., Fichaut, B., Suanez, S., David, L., Leckler, F., et al. (2016). A comprehensive hydro-geomorphic study of cliff-top storm deposits on Banneg Island during winter 2013-2014. Mar. Geol. 382, 37-55. doi: 10.1016/j.margeo. 2016.09.014

Baschek, B., Schroeder, F., Brix, H., Riethmüller, R., Badewien, T. H., Breitbach, G., et al. (2017). The coastal observing system for northern and arctic seas (COSYNA). Ocean Sci. 13, 379-410. doi: 10.5194/os-13-379-2017

Béthoux, J.-P., Morin, P., and Ruiz-Pino, D. (2002). Temporal trends in nutrient ratios: chemical evidence of mediterranean ecosystem changes driven by human activity. Deep Sea Res. Part II Top. Stud. Oceanogr. 49, 2007-2016. doi: 10.1016/ S0967-0645(02)00024-3

Béthoux, J.-P., and Tailliez, D. (1994). "Deep-Water in the Western Mediterranean Sea, Yearly Climatic Signature and Enigmatic Spreading," in Ocean Processes in Climate Dynamics: Global and Mediterranean Examples. NATO ASI Series (Series C: Mathematical and Physical Sciences), eds P. Malanotte-Rizzoli and A. R. Robinson (Berlin: Springer).

Blain, S., Guillou, J., Treguer, P., Woerther, P., Delauney, L., Follenfant, E., et al. (2004). High frequency monitoring of the coastal marine environment using the MAREL buoy. J. Environ Monitor. 6, 569-575. doi: 10.1039/b314073c

Bosse, A., Testor, P., Houpert, L., Damien, P., Prieur, L., Hayes, D., et al. (2016). Scales and dynamics of submesoscale coherent vortices formed by deep convection in the northwestern mediterranean sea. J. Geophys. Res. Oceans 121, 7716-7742. doi: 10.1002/2016jc012144

Bosse, A., Testor, P., Mortier, L., Prieur, L., Taillandier, V., D’Ortenzio, F., et al. (2015). Spreading of levantine intermediate waters by submesoscale coherent vortices in the northwestern mediterranean sea as observed with gliders. J. Geophys. Res. Oceans 120, 1599-1622. doi: 10.1002/2014jc010263

Burvingt, O., Masselink, G., Scott, T., Davidson, M., and Russell, P. (2018). Climate forcing of regionally-coherent extreme storm impact and recovery on embayed beaches. Mar. Geol. 401, 112-128. doi: 10.1016/j.margeo.2018.04.004

Castelle, B., Dodet, G., Masselink, G., and Scott, T. (2017). A new climate index controlling winter wave activity along the Atlantic coast of Europe: the West Europe pressure anomaly. Geophys. Res. Lett. 44, 1384-1392. doi: 10.1002/ 2016GL072379

Castelle, B., Dodet, G., Masselink, G., and Scott, T. (2018). Increased wintermean wave height, variability, and periodicity in the Northeast Atlantic over 1949-2017. Geophys. Res. Lett. 45, 3586-3596. doi: 10.1002/2017GL076884

Castelle, B., Marieu, V., Bujan, S., Splinter, K. D., Robinet, A., Sénéchal, N., et al. (2015). Impact of the winter 2013-2014 series of severe Western Europe storms on a double-barred sandy coast: beach and dune erosion and megacusp embayments. Geomorphology 238, 135-148. doi: 10.1016/j.geomorph.2015.03.006

\section{AUTHOR CONTRIBUTIONS}

$\mathrm{LuC}, \mathrm{CD}$, JP, and $\mathrm{PhR}$ contributed to the conception or design of the infrastructure. $\mathrm{LuC}, \mathrm{CD}$, and JP wrote the first draft of the manuscript. JA, BC, GC, JC, PC, LaC, RH, SP, PaR, NS, LT, and $\mathrm{RV}$ wrote sections of the manuscript.

\section{ACKNOWLEDGMENTS}

Stevenn Lamarche provided a major help for preparing the figures; Guy Woppelmann, Maud Lemoine, Pascal Claquin, and François Schmitt are acknowledged for their role in the coordination of ILICO observation networks and their useful comments on the manuscript.

Coppola, L., Legendre, L., Lefevre, D., Prieur, L., Taillandier, V., and Diamond Riquier, E. (2018). Seasonal and inter-annual variations of dissolved oxygen in the northwestern mediterranean Sea (DYFAMED site). Prog. Oceanogr. 162, 187-201. doi: 10.1016/j.pocean.2018.03.001

Damien, P., Bosse, A., Testor, P., Marsaleix, P., and Estournel, C. (2017). Modeling Postconvective submesoscale coherent vortices in the Northwestern Mediterranean Sea. J. Geophys. Res. Oceans 122, 9937-9961. doi: 10.1002/ $2016 \mathrm{jc} 012114$

Davies, H. C. (2015). Weather chains during the 2013/2014 winter and their significance for seasonal prediction. Nat. Geosci. 8, 833-837. doi: 10.1038/ ngeo2561

Davis, R. A., and Ethington, R. L. (1976). Beach and nearshore sedimentation. SEPM Soc. Sediment. Geol. 24. doi: 10.2110/pec.76.24

Dodet, G., Castelle, B., Masselink, G., Scott, T., Davidson, M., Floc'h, F., et al. (2019). Beach recovery from extreme storm activity during the 2013-14 winter along the Atlantic coast of Europe. Earth Surf. Process. Landf. 44, 393-401. doi: 10.1002/esp.4500

Donoso, K., Carlotti, F., Pagano, M., Hunt, B. P. V., Escribano, R., and Berline, L. (2017). Zooplanktoncommunity response to the winter2013 deep convection process in the NW Mediterranean Sea. J. Geophys. Res. Oceans 122, 2319-2338. doi: 10.1002/2016JC012176

Dumas, C., Ludwig, W., Aubert, D., Eyrolle, F., Raimbault, P., Gueneugues, A., et al. (2015). Riverine transfer of anthropogenic and natural trace metals to the Gulf of Lions (NW Mediterranean Sea). Appl. Geochem. 58, 14-25. doi: 10.1016/j.apgeochem.2015.02.017

Durrieu de Madron, X., Houpert, L., Puig, P., Sanchez-Vidal, A., Testor, P., Bosse, A., et al. (2013). Interaction of dense shelf water cascading and open-sea convection in the northwestern Mediterranean during winter 2012. Geophys. Res. Lett. 40, 1379-1385. doi: 10.1002/grl.50331

Galzin, R., Lecchini, D., Lison de Loma, T., Moritz, C., Parravicini, V., and Siu, G. (2015). Long term monitoring of coral and fish assemblages (1983-2014) in Tiahura reefs, Moorea, French Polynesia. Cybium 40, 031-041.

Goberville, E., Beaugrand, G., Sautour, B., Tréguer, P., and Team, S. (2010). Climate-driven changes in coastal marine systems of western Europe. Mar. Ecol. Prog. Ser. 408, 129-148. doi: 10.3354/meps08564

Hernández-Fariñas, T., Soudant, D., Barille, L., Belin, C., Lefebvre, A., Bacher, C., et al. (2014). Temporal changes in the phytoplankton community along the french coast of the eastern english channel and the southern bight of the North Sea. ICES J. Mar. Sci. 71, 821-833. doi: 10.1093/icesjms/fst192

Hocdé, R., and Fiat, S. (2013). Le système d'information du "réseau de capteurs de température des eaux côtières dans la région du Pacifique Sud et Sud-Ouest?". Netcom 27, 170-173. doi: 10.4000/netcom.1294

Houpert, L., Testor, P., Durrieu de Madron, X., Somot, S., D’Ortenzio, F., Estournel, C., et al. (2015). Seasonal cycle of the mixed layer, the seasonal thermocline and the upper-ocean heat storage rate in the mediterranean Sea derived from observations. Prog. Oceanogr. 132, 333-352. doi: 10.1016/j.pocean.2014.11.004

Hunt, B. P. V., Carlotti, F., Donoso, K., Pagano, M., D’Ortenzio, F., Taillandier, V., et al. (2017). Trophic pathways of phytoplankton size classes through the 
zooplankton food web over the spring transition period in the north-west Mediterranean Sea. J. Geophys. Res. Oceans 122, 6309-6324. doi: 10.1002/ 2016jc012658

Krahmann, G., and Schott, F. (1998). Longterm increases in Western Mediterranean salinities and temperatures: anthropogenic and climatic sources. Geophys. Res. Lett. 22, 4209-4212. doi: 10.1029/1998gl900143

Lamy, T., Galzin, R., Kulbicki, M., Lison de Loma, T., and Claudet, J. (2016). Three decades of recurrent declines and recoveries in corals belie ongoing change in fish assemblages. Coral Reefs 35, 293-302. doi: 10.1007/s00338-015-1371-2

Lemos, C., Floc'h, F., Yates, M., Le Dantec, N., Marieu, V., Hamon, K., et al. (2018). Equilibrium modeling of the beach profile on a macrotidal embayed low tide terrace beach. Ocean Dyn. 68, 1207-1220. doi: 10.1007/s10236-018-1185-1

Liénart, C., Savoye, N., Bozec, Y., Breton, E., Conan, P., David, V., et al. (2017). Dynamics of particulate organic matter composition in coastal systems: a spatio-temporal study at multi-systems scale. Prog. Oceanogr. 156, 221-239. doi: 10.1016/j.pocean.2017.03.001

Liénart, C., Savoye, N., David, V., Ramond, P., Rodriguez Tress, P., Hanquiez, V., et al. (2018). Dynamics of particulate organic matter composition in coastal systems: forcing of spatio-temporal variability at multi-systems scale. Prog. Oceanogr. 162, 271-289. doi: 10.1016/j.pocean.2018.02.026

Lorenzoni, L., and Benway, H. M. (2013). Global Intercomparability in a Changing Ocean: an International Time-Series Methods Workshop. Bermuda: Bermuda Institute of Ocean Sciences.

Many, G., Bourrin, F., Durrieu de Madron, X., Pairaud, I., Gangloff, A., Doxaran, D., et al. (2016). Particle assemblage characterization in the rhone River ROFI. J. Mar. Syst. 157, 39-51. doi: 10.1016/j.jmarsys.2015.12.010

Marchesiello, P., Lefèvre, J., Vega, A., Couvelard, X., and Menkes, C. (2010). Coastal upwelling, circulation and heat balance around New Caledonia's barrier reef. Mar. Pollut. Bull. 61, 432-448. doi: 10.1016/j.marpolbul.2010.06.043

Masselink, G., Castelle, B., Scott, T., Dodet, G., Suanez, S., Jackson, D., et al. (2016). Extreme wave activity during 2013/2014 winter and morphological impacts along the Atlantic coast of Europe. Geophys. Res. Lett. 43, 2135-2143. doi: 10.1002/2015GL067492

Masselink, G., Scott, T., Poate, T., Russell, P., Davidson, M., and Conley, D. (2015). The extreme 2013/2014 winter storms: hydrodynamic forcing and coastal response along the southwest coast of England. Earth Sur. Process. Landf. 41, 378-391. doi: 10.1002/esp.3836

Ouillon, S., Douillet, P., Fichez, R., and Panché, J.-Y. (2005). Enhancement of regional variations in salinity and temperature in a coral reef lagoon, New Caledonia. Comptes Rendus Geosci. 337, 1393-1582.

Petihakis, G., Perivoliotis, L., Korres, G., Ballas, D., Frangoulis, C., Pagonis, P., et al. (2018). An integrated open-coastal biogeochemistry, ecosystem and biodiversity observatory of the eastern mediterranean - the cretan sea component of the POSEIDON system. Ocean Sci. 14, 1223-1245. doi: 10.5194/ os-14-1223-2018

Picheral, M., Guidi, L., Stemmann, L., Karl, D. M., Iddaoud, G., Gorsky, G., et al. (2010). The underwater vision profiler 5: an advanced instrument for high spatial resolution studies of particle size spectra and zooplankton. Limnol. Oceanogr.. Methods 8, 462-473. doi: 10.4319/lom.2010.8.462

Pouvreau, N. (2008). Trois Cents ans de Mesures Marégraphiques en France: Outils, Méthodes et Tendances des Composantes du Niveau de la Mer au Port de Brest. Available at: https://tel.archives-ouvertes.fr/tel-00353660/document. (accessed September 26, 2008).

Ramondenc, S. (2017). Analyse Des Variations Spatio-Temporelles Du Zooplancton Gélatineux et Son Effet Sur Les Flux De Matières à l'aide d'une Approche Combinant Expérimentation et Écologie Numérique. Paris: Ecologie, Environnement. Université Pierre et Marie Curie.

Rixen, M., Beckers, J. M., Levitus, S., Antonov, J. T., Boyer, T. C., Maillard, C., et al. (2005). The western mediterranean deep water: a proxy for climate change. Geophys. Res. Lett. 32:L12608. doi: 10.1029/2005GL022702

Robinet, A., Idier, D., Castelle, B., and Marieu, V. (2018). A reducedcomplexity shoreline change model combining longshore and cross-shore processes: the lx-shore model. Environ. Model. Soft. 109, 1-16. doi: 10.1016/j.envsoft.2018.08.010

Rohling, E. J., and Bryden, H. L. (1992). Man-induced salinity and temperature increases in western mediterranean deep water. J. Geophys. Res. 97, 1119111198. doi: 10.1038/srep23009

Rombouts, I., Simon, N., Aubert, A., Cariou, T., Feunteun, E., Guérin, L., et al. (2019). Changes in marine phytoplankton diversity: assessment under the marine strategy framework directive. Ecol. Indic. 102, 265-277. doi: 10.1016/ j.ecolind.2019.02.009

Sadaoui, M., Ludwig, W., Bourrin, B., and Raimbault, P. (2016). Controls, budgets and variability of riverine sediment fluxes to the Gulf of lions (NW Mediterranean Sea). J. Hydrol. 540, 1002-1015. doi: 10.1016/j.jhydrol.2016.07.012

Send, U., Font, J., Krahmann, G., Millot, C., Rhein, M., and Tintoré, J. (1999). Recent advances in observing the physical oceanography of the western Mediterranean Sea. Prog. Oceanogr. 44, 37-64. doi: 10.1016/S0079-6611(99) 00020-8

Somot, S., Houpert, L., Sevault, F., Testor, P., Bosse, A., Taupier-Letage, I., et al. (2016). Characterizing, modelling and understanding the climate variability of the deep water formation in the North-Western Mediterranean Sea. Clim. Dyn. 51, 1179-1210. doi: 10.1007/s00382-016-3295-0

Splinter, K. D., Turner, I. L., Davidson, M. A., Barnard, P., Castelle, B., and Oltman-Shay, J. (2014). A generalizedequilibrium model for predicting dailyto interannual shoreline response. J. Geophys. Res. Earth Surf. 119, 1936-1958. doi: 10.1002/2014jf003106

Talarmin, A., Lomas, M. W., Bozec, Y., Savoye, N., Frigstad, H., Karl, D. M., et al. (2016). Seasonal and long-term changes in elemental concentrations and ratios of marine particulate organic matter. Global Biogeochem. Cycles 30, 1699-1711. doi: 10.1002/2016GB005409

Testut, L., Wöppelmann, G., Simon, B., and Téchiné, P. (2006). The sea level at Port-aux-Français, Kerguelen Island, from 1949 to the present. Ocean Dyn. 56, 464-472. doi: 10.1007/s10236-005-0056-8

Thorel, M., Claquin, P., Schapira, M., Le Gendre, R., Riou, P., Goux, D., et al. (2017). Nutrient ratios influence variability in pseudo-nitzschia species diversity and particulate domoic acid production in the Bay of Seine (France). Harmful Algae 68, 192-205. doi: 10.1016/j.hal.2017. 07.005

Vitousek, S., Barnard, P. L., Limber, P., Erikson, L., and Cole, B. (2017). A model integrating longshore and cross-shore processes for predicting long-term shoreline response to climate change. J. Geophys. Res. Earth Surf. 122, 782-806. doi: 10.1002/2016JF004065

Widdicombe, C. E., Eloire, D., Harbour, D., Harris, R. P., and Somerfield, P. J. (2010). Long-term phytoplankton community dynamics in the Western English Channel. J. Plankton Res. 32, 643-655. doi: 10.1016/j.marenvres.2017. 04.013

Wilkinson, M. D., Dumontier, M., Aalbersberg, I. J., Appleton, G., Axton, M., Baak, A., et al. (2016). The FAIR guiding principles for scientific data management and stewardship. Sci. Data 3:160018

Wiltshire, K. H., Kraberg, A., Bartsch, I., Boersma, M., Franke, H.-D., Freund, J., et al. (2010). Helgoland Roads, North Sea: 45 Years of Change. Estuaries Coast. 33, 295-310. doi: 10.1007/s12237-009-9228-y

Woppelmann, G., Pouvreau, N., and Simon, B. (2006). Brest sea level record: a time series construction back to the early eighteenth century. Ocean Dyn. 56, 487-497. doi: 10.1007/s10236-005-0044-z

Yates, M., Guza, R., O’Reilly, W. C., and Seymour, R. J. (2009). Overview of seasonal sand level changes on Southern California beaches. Shore Beach. 77, 1-46.

Zappa, G., Shaffrey, L. C., Hodges, K. I., Sansom, P. G., and Stephenson, D. B. (2013). A Multimodel assessment of future projections of north atlantic and european extratropical cyclones in the cmip5 climate models. J. Clim. 26, 5846-5862. doi: 10.1175/jcli-d-12-00573.1

Conflict of Interest Statement: The authors declare that the research was conducted in the absence of any commercial or financial relationships that could be construed as a potential conflict of interest.

The handling Editor declared a shared affiliation, though no other collaboration, with one of the authors JC at the time of review.

Copyright (C) 2019 Cocquempot, Delacourt, Paillet, Riou, Aucan, Castelle, Charria, Claudet, Conan, Coppola, Hocdé, Planes, Raimbault, Savoye, Testut and Vuillemin. This is an open-access article distributed under the terms of the Creative Commons Attribution License (CC BY). The use, distribution or reproduction in other forums is permitted, provided the original author(s) and the copyright owner(s) are credited and that the original publication in this journal is cited, in accordance with accepted academic practice. No use, distribution or reproduction is permitted which does not comply with these terms. 